\title{
Westminster in Small States: Comparing the Caribbean and Pacific Experience
}

\author{
Jack Corbett $^{\mathrm{a}}$ and Wouter Veenendaal ${ }^{\mathrm{b}}$ \\ ${ }^{a}$ Associate Professor in Politics, Politics and International Relations, University of
}

Southampton

${ }^{b}$ Postdoctoral Fellow, Royal Netherlands Institute of Southeast Asian and Caribbean Studies

* A slightly amended version of this paper is forthcoming in the journal Contemporary Politics

\begin{abstract}
Small states, and those in the Caribbean and Pacific regions in particular, are among the most stubbornly and disproportionally democratic countries in the world. And yet, they are rarely studied comparatively, despite sharing seemingly obvious similarities - aside from being small island states with developing economies they also tend to share a British colonial heritage and Westminster-inspired political institutions. This omission is all the more puzzling if we consider that the group does not conform to the standard battery of explanations developed by democratization theorists. To pave the way for further research across these two regions, this article provides a synoptic comparison of the process of democratization in Caribbean and Pacific small states. We highlight important similarities and differences that stem from the interaction between formal institutions and informal practices. We conclude by reiterating the benefits for scholars of democratization by looking at these significant yet hitherto rarely compared cases.
\end{abstract}

Keywords: democratization, Westminster, small states, Pacific, Caribbean 


\section{Introduction}

Democracy promotion has become an important feature of international relations over recent decades, as evidenced by the influence of rankings like Freedom House and the flow of aid money to organisations that undertake this type of work. For supporters, democracy is a universal good whose instrumental virtues are illustrated by the attainment of 'democratic peace', among other things (for discussion see Burnell and Schlumberger 2010). For critics, interventions undermine state sovereignty and indigenous efforts to maintain political order (e.g. Hameiri 2009). Putting these normative discussions aside, the agenda rests on attempts to explain why certain countries and regions are more likely than others to be democratic. The world's smallest states, many of which are located in the Caribbean and Pacific regions, represent an anomaly for democratization scholars. ${ }^{1}$ On the one hand, Freedom House ranks them as stubbornly and disproportionately democratic (Diamond \& Tsalik, 1999; Ott, 2000; Anckar, 2002; Srebrnik 2004). On the other hand, as a group they do not conform to the standard preconditions - economic growth, educated middle class, social homogeneity etc. (see Przeworski et al., 2000; Barro, 1999) - typically identified by modernization theory as necessary for sustained democratic transition (Veenendaal and Corbett 2015).

The theoretical significance of these cases, however, belies the virtual absence of any comparative studies of democratic practice. Indeed, the literatures on the politics of each region are more likely to reference theoretical texts from Africa or Latin America than their more obviously similar equivalents. This absence of comparison is even more surprising when we consider that aside from being small states with developing economies, countries in both

\footnotetext{
${ }^{1}$ As most publications in the field of comparative politics have done, we conceptualise state size on the basis of population (Crowards 2002, Alesina and Spolaore 2005, Anckar 2010). In doing we so we acknowledge the endogenous limitations of this approach, including the extent to which the label 'small' can belittle the countries in question (Hau'ofa 1994). In addition, most of the countries we consider here are not just small states but also island states. We will briefly consider the importance of this below but for a further discussion of why islands constitute important research categories in their own right see Baldacchino (2008).
} 
regions share a British colonial heritage and associated Westminster institutions, factors that some scholars argue have important democracy-stimulating effects (Weiner 1987, Ghai 1988, Hadenius 1992; Clague et al. 2001). Moreover, even the most cursory glance at the area studies literature from both regions reveals a host of similarities in the way democracy is practised in these settings, with executive domination and patron-client politics especially prominent (e.g. Peters 1992; Hinds 2008; Duncan and Hassall 2011; Quinn 2015; Veenendaal 2013; Corbett and Wood 2013).

This article aims to compare democratic practices in both regions in order to consider what lessons they might offer of the study of democratization. To do so we ask how British colonial heritage and associated Westminster institutions have influenced the democratization process in the Caribbean and Pacific. Our comparison is synoptic: we provide a broad coverage (19 country cases) that aims to map out an explanatory approach. As a result, in this article we primarily intend to develop a number of descriptive inferences (Gerring 2012) about the practice of democracy and the Westminster system in small states. We adopt Hall and Taylor's well-known definition of political institutions as "the formal or informal procedures, routines, norms and conventions embedded in the organizational structure of the polity" (1996: 938), and on this basis we define Westminster as a parliamentary system of government characterised by the fusion of executive and legislative powers. ${ }^{2}$

Aside from Freedom House, small states are systematically excluded from the major democracy databases - i.e. Democracy Index and Polity IV (Veenendaal and Corbett 2015). So, to make our case we draw on the substantial area studies literature on small states

\footnotetext{
${ }^{2}$ In addition to these benchmarks, institutional characteristics commonly associated with the Westminster model are 1) a ceremonial head of state (usually a monarch), 2) a non-proportional electoral system, 3) an independent, non-partisan civil service, and 4) a bicameral parliament. Some but not all of these features are apparent in the countries considered here.
} 
combined with our own interview work on the beliefs and practices of government elites in the Pacific and Caribbean (e.g. Veenendaal 2014; Corbett 2015b). This material is qualitative and defies the types of sampling conventions common to positivist social science, but for the purposes of this synoptic comparison it offers insights that could not be obtained via other means. ${ }^{3}$ We organize our discussion around five questions adapted from Rhodes, Wanna and Weller's (2009) recent study of Westminster in Britain, Canada, Australia, New Zealand and South Africa. And so, in addition to contributing to the literature on democratization, the article also adds to the comparative study of Westminster government.

\section{<INSERT TABLE: WESTMINSTER IN THE CARIBBEAN AND PACIFIC $>$}

Faced with similar material conditions (small island developing economies) and shared heritage and institutions, we would expect that political practice would have developed in similar ways. In some ways it has: the ubiquity of personalisation and patron-client politics is common to both regions. But, in other instances there are marked differences, including the relative importance of political parties, for instance. Both types of insights offer important lessons for students and scholars of democratization interested in the causes of transformation and consolidation. Our synoptic comparison suggests that Westminster traditions continue to shape democratic practice in small states but this relationship is not linear or deterministic. That is, British colonial heritage has clearly influenced how democracy is practised in the small states of the Pacific and Caribbean but not in the manner that existing scholarship (e.g. Weiner 1987, Ghai 1988, Hadenius 1992; Clague et al. 2001) predicts. Most obviously, democratic practice in the post-colonial Pacific and Caribbean has been marked by significant innovation and adaptation, much of which has occurred in response to challenges arising from

\footnotetext{
${ }^{3}$ It also reveals that while there are important similarities and differences between the two areas of the world, in some instances it makes more sense to compare countries - Trinidad and Tobago and Fiji, for instance, with their shared experience of indenture - and so the article moves back and forth between these two units of analysis.
} 
the small size of political units. We argue that research on decisions to persist with or change Westminster institutions in these contexts provides one of the most fruitful avenues for future comparative research between these two areas of the world.

\section{Explaining the Impact of British Colonial Heritage on Democratisation}

The small literature on democracy-stimulating effects of British colonial heritage has largely been developed from the Caribbean experience. Combined, it identifies four factors that explain the disproportionately successful transition of these states: 1) prolonged socialization, 2) vulnerability and openness, 3) the absence of a colonial struggle, and 4) institutional fidelity. Here, we briefly flesh each of these arguments out to highlight our contribution but also the potential for future research to inform this discussion. ${ }^{4}$

The first argument for why British colonial heritage can explain the disproportionately successful democratization of small states is heavily based on the experience of the Eastern Caribbean, which was first colonised in the 1600s. Weiner (1987) and Baldacchino (1993) both observe that colonization actually created many of these small states through forced migration, and so officials had considerable time and opportunity to inculcate slave populations in their political traditions. Similarly, Payne (1993: 9) argues that because the Eastern Caribbean island states were "socialized by over three hundred years of British colonialism, the emergent Commonwealth Caribbean elite could scarcely have become anything else other than liberal democracies" (cf. Duncan and Woods 2007: 205). The argument is that sustained exposure to Westminster traditions and beliefs ensured that local elites were well versed in their operation at independence. As a result, because this way of

\footnotetext{
${ }^{4}$ We adapt Rhodes et al.'s (2009) framework in our substantive discussion as it speaks to the significance of British colonial heritage as a distinct set of democratic practices rather than the nature of colonial rule which, as a determining variable, could equally be applied to French colonisation in the Pacific and Caribbean, for example.
} 
governing had an established routine, transition was less complex in small states relative to other parts of the world where Westminster institutions had only recently been transferred.

The second argument is that the smallness and vulnerability of the Caribbean and Pacific Island colonies meant that the impact of colonialism was more profound relative to say African countries, where the presence of the British colonial administrators was restricted to capital cities and a few key outposts. According to Baldacchino (1993: 31), for example, colonialism played a particularly influential role in small states because many were islands whose native population was either rapidly assimilated or annihilated (and some had none at all). For Baldacchino (1993: 31) and others the 'penetration' of colonialism in small states means their populations are more 'westernized' than other colonized societies (inter alia Caldwell 1980: 560; Sutton 1987: 9-12). This argument is similar to the first assertion in that both focus on socialization, but it differs in that it sees the key factor as intensity rather than length of colonial tenure.

The third argument is that the process of decolonization in small states can explain the increased likelihood that they would both adopt and maintain a democratic system after independence. As Baldacchino again argues, "few [small states] actually struggled for independence; for many, the process was undramatic, somewhat haphazard, or even sudden" (1993: 31, italics in original). In fact, for many island nations independence was initiated by colonial powers, who by the 1970 s had come to regard the lasting colonial relationship as disreputable and therefore undesirable (Hoefte and Oostindie 1991: 93). ${ }^{5}$ From the perspective of small states, the absence of a (violent) colonial struggle and the relatively

\footnotetext{
${ }^{5}$ The progress towards independence was mostly also stringently controlled by the colonial powers (see Ghai 1988: 4-6 and Levine 2009 for Pacific microstates). In some microstates (e.g. St. Kitts and Nevis, Vanuatu, and Kiribati), independence was delayed due to lingering tensions between various islands, which had to be resolved before London would permit self-rule.
} 
peaceful transition is said to indicate a relative acquiescence to intervention and thus tacit acceptance of the political institutions of departing colonizers.

As a fourth and final distinctive characteristic of the small state-colonial legacy, some have emphasized the propensity of small states to adopt and retain the political institutions of their former colonizer (Sutton 1987: 8-12, Sutton and Payne 1993: 586-587). This "institutional fidelity" (Sutton 2007: 202) can on the one hand be explained by the more prolonged and profound colonial experience described above, but has also been attributed to the relative lack of highly-educated legal experts in small island nations, as a result of which potential alternatives proposed by departing colonial powers were not well known. In which case, institutional isomorphism can explain the durability of Westminster systems in the Caribbean and Pacific irrespective of its suitability. This is similar to the previous argument about the absence of a prolonged or violent independence struggle in small states but instead of emphasizing the unwillingness of small state elites to resist colonial direction it stresses their incapacity.

Taken together, these four general characteristics of colonization and decolonization in small states are said to explain the persistence of the Westminster system in former British island colonies. Yet, as we will show, the area studies literatures on the performance of Westminster in these same small states emphasizes that these political institutions do not function according to the established logics and dynamics that have been observed in larger countries. By combining this material with our own research we challenge the above four assumptions. But, in doing so we do not dismiss the influence of British colonial heritage entirely. Instead, we show how its norms and values have been adapted in interesting and innovative ways. Furthermore, we demonstrate that the deviations from the classic Westminster model we 
observe can be explained on the basis of one key factor that Caribbean and Pacific island states share: their (very) small size.

\section{Westminster in the Caribbean and the Pacific}

\section{Westminster as Inheritance}

In the British empire the great self-governing dominions beyond the seas have not only copied British forms of parliamentary government but have inherited British traditions, usages, and modes of thought (former Clerk of the House of Commons cited in Rhodes et al. 2009: 11).

Almost all countries with a Westminster system share a common British colonial heritage (Rhodes et al. 2009: 20). As a result, for the most part the literature on small states supports the view of Westminster as 'shared inheritance', even if it does not go into great detail about how this inheritance influences everyday democratic practices. Moreover, since decolonization organizations like the Commonwealth Parliamentary Association have actively encouraged this sense of common heritage among parliamentarians and political elites, in particular through discussion and debate of shared traditions. Indeed, despite historical divergences, customs that have since been abandoned large states persist in small ones. For example, in his study of the Office of the Speaker across the Commonwealth, Matthew Laban (2014) finds that while the House of Commons has evolved, certain Commonwealth legislatures have clung on to ancient traditions: they are often 'more Westminster than Westminster'. Like Rhodes et al. (2009), Laban (2014) largely focuses on the experience of the five 'great self-governing dominions' but he does include small states in his discussion of traditional regalia, including the wig and gown, noting that several small states in the Pacific and Caribbean persist with it. Moreover, he reports that the Clerk of the House of Commons 
regularly receives requests for advice from around the Commonwealth on how to resolve matters of procedure. His conclusion is that inheritance is not just a relic of the past but persists into the present, and as a result his analysis supports the emphasis on socialisation and institutional fidelity outlined above. This can essentially be seen as a path-dependence argument.

Not all examples support his view, however, with the colonial inheritance and Westminster traditions often subject to considerable adaptation in small states. Marshall Islands, for example, has a 'hybrid' Westminster and Presidential system where the President is both head of government and head of state. In practice this results in the Marshallese constitution conforming to the Westminster tradition of the Prime Minister being drawn from parliament with their cabinet responsible to it for all decisions (Rhodes et al. 2009: 7). This arrangement is not unique - Nauru essentially has the same model - as having both a head of state and head of government was considered extravagant given the size of both the country and the legislature (Wettenhall and Thynne 1994: 70). ${ }^{6}$ However, whereas Nauru has an indirect Commonwealth heritage by virtue of being a former trust territory of Australia, Marshall Islands, successively subject to the administrative control of Germany, Japan and US, does not.

As outlined above, the existing literature on Westminster in small states emphasises the length and intensity of British colonial rule to explain the persistence of Westminster institutions. The Marshall Islands case challenges this view as it is an example of Westminster being adopted in a country that was never British. We thus need to stretch the common understanding of how 'heritage' is both transferred and interpreted if we want to understand

\footnotetext{
${ }^{6}$ These 'presidentialized' Westminster systems, where a parliamentary system exists in conjunction with an executive presidency, also exists in Botswana and South Africa. In these and other polities narratives about 'presidentialism' and 'Westminster' often exist side-by-side.
} 
how this process occurred in Marshall Islands. Other important exceptions include Tonga, which was never formally colonized and yet British influence was decisive in its institutional arrangements, Kiribati, a former British colony that opted for a directly elected President drawn from a shortlist of MPs, or Seychelles, a former British colony with a full-fledged presidential system. Reflecting our emphasis on the effects of smallness, it is worth noting that in adopting Westminster traditions the founders of the Marshallese constitution turned away from their US colonial heritage in the belief that Westminster better suited local traditions (Larmour 2005b: 226). We will discuss this case in further detail below but for now the important point is that in contrast to the path dependence outlined above, in some cases the choice of Westminster might be better described as deliberate and calculated.

\section{Westminster as a Political Tool}

Westminster has a rhetorical quality that politicians draw upon to either justify their actions or accuse their opponents of transgressing the rules (Rhodes et al. 2009: 221). The term plays well in the arena, amongst the cut and thrust of parliamentary debate. Recognition that Westminster can be exploited as a political tool is largely overlooked in the literature on British colonial heritage and democratisation. It does, however, have profound implications for that argument as it emphasises the agency of those involved and the manner in which their interpretations shape outcomes. For example, one of the core beliefs about Westminster that Rhodes et al. (2009: 7 and 71) identify is that the majority party controls both the executive and parliament but is held accountable by a "loyal" opposition. In small states, this tradition has diverged in two main ways.

In the Anglophone Caribbean, scholars increasingly argue that Westminster institutions are unsuitable to the Caribbean political context as they primarily generate extreme partisan 
polarization, top-down authoritarian leadership, the victimization of political opponents, and the exploitation of state resources to finance clientelism and patronage (Peters 1992: 21; Ryan 1999: 317; Duncan and Woods 2007: 211-213; Hinds 2008: 394-395; Girvan 2015: 101-102). As a result, the political opposition in Anglophone Caribbean islands is often completely ignored and excluded from political decision-making, which greatly undermines their political function. Indeed, while small states are renowned for their statistical correlation with democratic government, they are also disproportionately susceptible to domination by leaders capable of controlling nearly all aspects of political and social life (Baldacchino 2012; Erk and Veenendaal 2014). In the case of Antigua and Barbuda, for example, the Bird family controlled Antigua Labour Party governed from 1951 to 2004. This tendency for small-scale personality driven politics to having varying and seemingly contradictory effects was first theorized by Dahl and Tufte (1973: 15) who highlighted how the personalization of politics can paradoxically make leaders both more and less responsive (see also Veenendaal 2013). In which case, small states in the Caribbean and Pacific provide important empirical examples of this dynamic tension in action.

The second divergence is in those countries where party politics is almost entirely absent. Legislative-executive fusion is, relative to a Presidential or consensual system, supposed to provide governing parties with stability. However, in many Pacific small states it has had the opposite effect, as political parties constitute loose coalitions rather than institutionalized machines. Indeed, some Westminster systems, like Tuvalu, do not have parties at all. In these cases Westminster can actually function much more like 'consensus' democracies than 'majoritarian' ones, to borrow from Lijphart's (1999) taxonomy, due to the constant manoeuvring by members seeking to establish ruling coalitions. In such instances, tactics like votes of no confidence that, in the five 'great self-governing dominions' have theatrical 
appeal but lack consequence, assume great significance with governments regularly toppled by the decision of one or two members of parliament (MP) to cross the floor. In these cases, Westminster traditions have been interpreted in the opposite way to that which was initially intended. The lesson is that while Westminster can be a 'political tool' in small states, the effects challenge the assumptions that democratic transition has been a unalloyed success. Rather, the success or otherwise of Westminster is the subject of intense debate in small states with different sides of politics using the term to either legitimise their actions or delegitimise those of their opponents. Most importantly, in relation to the four arguments outlined above, the use of Westminster as a political tool in small states points us away from the path dependent nature of colonial socialisation and towards a more dynamic and iterative interpretation of the ways British colonial heritage has shaped democratization.

\section{Westminster as a Legitimizing Tradition}

One aspect of Westminster is that it inspires nostalgia for a time or place when government functioned differently to the way it does today. The point is that as a 'legitimizing tradition' Westminster provides actors with an appeal to a past way of practice. The example Rhodes et al. (2009: 228) employ is of civil servants who use Westminster as a category to advance their power and status but also to protect their impartiality in the face of managerial reform. Westminster, in this example, becomes a point of reference, albeit idealized and reified. Given that the shared inheritance of Westminster is also a feature of politics in many small states it should not come as a surprise that appeals to a purer form of Westminster are often employed by political elites to legitimise their opposition to the types of patronage-based winner takes all politics outlined above. However, more commonly Westminster has become a negative symbol of colonial intervention. In which case, contra to the socialisation explanations 
outlined above, appeals to Westminster serve to delegitimise democratic practices in favour of alternative political regimes.

The key factor here is that unlike the five 'great self-governing dominions' that Rhodes et al. (2009) consider, all of which are settler societies, and the emphasis in the existing literature on small state acquiescence to colonial rule, Westminster faces considerable local resistance. As Larmour (2005a) notes, for example, in the Pacific Westminster is often seen as a negative symbol of introduced government that stands in opposition to traditional forms of authority. In countries, like Tonga and Fiji, where democratic transition has been most staunchly opposed, Stephanie Lawson (1996) finds conservative elites refer to the idea of representative government in a Westminster mould as 'democrazy' (the equivalent term in the Caribbean is 'Westmonster'). She cites a statement by an adviser to former President of Fiji, Ratu Sir Penaia Ganilau, that sees Westminster democracy as:

... contrary to the Fijian way of life where liberty exists only within one's own social rank and equality is constrained by a fully developed social hierarchy (Lawson 1996:171; cf. Ravuvu 1991: 87).

This type of account, and by extension the distinction between settler and colonial societies, tends to result in new practices becoming dogged by the 'spectre of inauthenticity' (Jolly 2002), leading to an insider-outsider distinction in which Westminster is portrayed as foreign or imported and compared unfavourably with the harmony and consensus of traditional rule (see also Lawson 2006). 
To deal with this dilemma, numerous countries in the Pacific enshrined traditional leaders a role in their constitutions. Fiji's pre-2006 Great Council of Chiefs is perhaps the most prominent example but this type of practice has been retained across the region despite mixed results (for discussion see Larmour 2005a: 67-86). Aside from divine right, in such cases, 'the argument against Westminster becomes one for decentralization or federalism in order that introduced systems can more closely approximate the scale of indigenous ones' (Larmour 2005b: 232; his book is entitled Foreign Flowers to capture this sentiment). There is a great deal of nostalgia tied up in this view. As Larmour (2005a: 84-6) points out, Westminster was actually rarely uniformly imposed with independence leaders choosing it from amongst a limited pool of alternatives, as we saw with Marshall Islands. Moreover, as we see repeatedly in Fiji, elites return to Westminster, or a modified version of it, after coups because it retains legitimacy in the eyes of the international community (Lawson 1996: 160). But, despite these caveats, Westminster has tended to function as a delegitimizing tradition in the Pacific.

The Caribbean's longer colonial history makes its experience different again. On one hand, a path dependence argument supports the above view that Westminster is autochthonous to the region (Sutton 1999: 69). For over three hundred years, the small European elite of the islands used Westminster institutions to dominate, exploit, and oppress the black working class, and although the system essentially excluded the plantation workers from political participation and involvement, it is nevertheless said to have had a large impact on political socialization (Peters 1992: 25-26). As Sutton (1999: 68) argues, “the Westminster model (...) has taken root in the Caribbean and has enjoyed widespread support." On the other hand, the strong link between the traumatic memory of slavery and Westminster institutions means that the term may carry negative connotations that are perhaps more plainly visible in the Caribbean relative to elsewhere (Hinds 2008: 396-397). Like the Pacific, Westminster institutions were 
maintained after independence and are valued for upholding political stability in the region (Domínguez 1993). However, critics argue that because the people of the Eastern Caribbean only experienced the potentially oppressive and authoritarian features of Westminster institutions, they have since replicated these features themselves (Peters 1992: 25-26). Accordingly, polarization, top-down government, victimization, and oppression mark the practice of Westminster in much of the region, leading some commentators to argue that it hardly deserves a democratic label (see Peters 1992).

One of the most pertinent examples of dissatisfaction with the authoritarian features of the Caribbean Westminster system is Grenada. Between 1979 and 1983 the Marxist-inspired New Jewel Movement (NJM) came to power on the back of a 'black power' ideology, which had rapidly become popular throughout the region during the 1970 s. $^{7}$ They rode a wave of populist disenchantment with the authoritarian and increasingly erratic leadership of Eric Gairy, who had ruled the country as Prime Minister under a Westminster system since 1967 (Archer 1985: 91, Thorndike 1993: 163; Clegg and Williams 2013; cf. Quinn 2013). The movement criticized the "two-second" democracy of the Westminster system because it stymied mass democratic participation, and was in general associated with oppressive colonial rules and the legacy of slavery (Thorndike 1993: 163). After gaining power the NJM swiftly transformed Grenada into an authoritarian single-party state, until the American invasion of 1983 ousted the regime and reinstalled multiparty democracy and the Westminster system.

So, rather than inheritance, reference to Westminster as an imposed system of rule is a tradition that features in the political discourse almost everywhere outside Britain. Placing too much emphasis on imposition can, however, be misleading as it obscures our understanding

\footnotetext{
${ }^{7}$ Jewel stands for "joint endeavor for welfare, education, and liberation."
} 
of why Westminster was chosen for small states in the first place. As we saw, the Marshallese example is the most instructive here. At independence, Marshallese elites rejected a US style presidential system in favour of a Westminster-inspired setup (although they call the head of government president rather than prime minister). In making this case to the 1975 Micronesian Constitutional Convention, Amata Kabua, a high chief by birth who became the country's longest serving president, argued that the system was a better fit with Marshallese culture than presidentialism. In particular, he extolled the facility to make collective decisions through group discussion in a parliamentary system rather than the open and frank debate among individuals that is a hallmark of republican adversarialism (Underwood 2006: 18). As Table 1 demonstrates, similar adaptations have occurred across the Pacific and account for the great diversity of constitutional types and electoral systems (for further discussion see Levine 2009).

This local desire to foster consensus echoes similar sentiment about 'democrazy', but, in this case, the argument is made in favour of Westminster not in opposition to it. One explanation for the difference, Underwood (2006: 18) argues, is that Kabua felt Westminster would help him consolidate power. Certainly, like other high chiefs - Fiji's Ratu Mara, for example who dismissed the system as 'alien' but later became prime minister, Kabua had five consecutive terms in office. Political elites who chose Westminster at independence usually had some experience of how the system functioned, which helps us make some sense of their choice; it was familiar (Larmour 2005b). Unlike these other leaders, however, Kabua had not spent time in a colonial legislative assembly run along Westminster lines - his primary preindependence experience as a legislator was in the US-inspired Congress of Micronesia which is why his public stance helps us problematize the blanket assumption that Westminster was always inherited or imposed; initially it was chosen, even if the pool of alternatives was 
small, and since independence the manner of its adaptation reflects the way local actors have employed it to their advantage (see also Kumarasingham 2013b: 593).

\section{Westminster as an Institutional Category}

As we saw, despite divergent choices at independence small states are said to have retained the institutional features bequeathed to them by their former colonisers, and this 'fidelity' is said to help explain their sustained transition (Sutton and Payne 1993: 586-587; Sutton 2007: 202-203). This view is, however, somewhat at odds with persistent institutional reforms that have become a hallmark of post-colonial politics in Pacific small states in particular where, in response to the perceived problems of Westminster, outlined above, many have experimented with innovative institutional arrangements. In Fiji, the now abrogated 1997 constitution experimented with a multi-party cabinet, which challenged the Westminster tradition of ministerial responsibility:

The 2006 budget, [out of] 9 FLP [Fiji Labour Party cabinet] members ... only four of us were in parliament on that day, the voting day. The others, they thought that they might lose their seat, the ministerial seat, and they went away somewhere on a bullshit ministerial visit overseas ... Four of us stayed and we voted against the budget ... We thought that if party principles says this then we should stick to the party... (author's interview with Fijian politician, 2011)

As outlined, in other Pacific countries the absence of institutionalised political parties has led to the consideration and in some cases adoption of party strengthening legislation that restricts the movement of members between government and the opposition (see Fraenkel 2012; Paeniu 2012). Conversely, Kiribati's relative stability is said to be a result of constitutional 
provisions that provide for: term limits (the 'president' is popularly elected but nevertheless holds a seat in parliament, as does the cabinet); a restriction on the number ministerial portfolios (in other countries MPs tend to leave the government in order to gain a better portfolio from the opposition); and a provision that a successful vote of no-confidence automatically triggers fresh elections (Paeniu 2012). In Samoa, the Human Rights Protection Party has governed for close to thirty years. Its stranglehold on power is often explained by a combination of cultural factors and strategic institutional reforms (So'o 2008; Iati 2013).

Not all innovations relate to the executive. Tuvalu has a unicameral parliament along Westminster lines but bills are referred to island councils (effectively local government) after the first reading for consultation and comment (Levine 1992). Despite this, and the fact that Tuvalu has a population of little over 10,000 people, dissatisfaction with the centralising tendencies of Westminster resulted in the Falekaupule Act 1997, which further devolved powers to each island council. As a result, they undertake many of the responsibilities conventionally reserved for national governments (Panapa and Fraenkel 2008). What's more, due to a belief among elites that its 15 -member parliament lacked the capacity to properly scrutinise complex financial documents and reports, Tuvalu's public accounts committee has, in recent years, taken to co-opting members of the public to assist with inquiries (Corbett 2015b). In all cases, these innovations highlight how small states have taken an institutional system ostensibly designed for large states and adapted it to suit the circumstances and conditions of their size (Wettenhall and Thynne 1994).

The Caribbean experience is slightly different as institutional reforms are yet to eventuate but, as David Hinds (2008: 388) outlines, "there is a growing consensus among scholars and politicians that a modification of the Westminster electoral system is a prerequisite for further 
democratization and political and economic advance in the region." Under the leadership of Ralph Gonsalves, the government of St. Vincent and the Grenadines has moved the furthest in addressing constitutional reform, despite a Reform Bill having been defeated in a 2009 national referendum (Bishop 2010: 432-433). This setback aside, the Vincentian reform process started out with a great deal of enthusiasm, and it seems that political reforms are now more firmly on the Caribbean political agenda than ever before. However, as Bishop (2010: 433) highlights, it is questionable whether political reforms can cure extremely adversarial and personal forms of political competition. In addition, since the Westminster model itself has developed incrementally, political reform in the Caribbean is more likely to result in some adapted form of the model rather than a complete relinquishment of Westminster traditions.

The lesson from both regions is that Westminster is not a fixed institutional category, but rather it diverges in response to local traditions that, in the case of small states, often stem from dilemmas posed by their size. The significance of this point is twofold: first it undermines the view that socialisation and the nature of colonial rule is the key determinant of democratisation trends; and second it highlights that elite actors in particular have a considerable amount of discretion over the direction in which political practices and institutional reforms take.

\section{Westminster as an Effective Political System}

The literature on British colonial heritage and democratization largely overlooks the effectiveness question - whether the systems is seen to work - despite its relevance: if British colonial heritage is in fact a decisive democracy stimulating factor, one obvious reason is that it is because Westminster is widely regarded as the best form of government in this context. By contrast, the question of effectiveness predominates the area studies literature on 
democracy in small states with aid donors increasingly interested in promoting 'good governance'. Donor interventions include everything from institutional strengthening designed to improve oversight and accountability mechanisms (see Kinyondo and Pelizzo, 2013) to forms of party aid (see Burnell and Gerrits, 2010) intended to fix the instability issues discussed earlier. Electoral engineering is also a common donor remedy in the Pacific, with preferential voting replacing the first-past-the-post electoral system in Fiji, for example (see Reilly 2001; Fraenkel 2004).

Following a linear modernization narrative, the underlying assumption is that the practice of politics in these new democracies has not 'developed' to the extent that it has in places like Britain, but that specific interventions might nudge it in the right direction. This tradition has strong Weberian undertones. It advances a version of Westminster where the state is analytically detached from society; is impartial and immune to patronage and nepotism; and has secured a monopoly over the legitimate use of violence. There are numerous critiques of this agenda and the ways they have been transferred to developing countries that we will not rehash here. The important point, from our perspective, is that scale and the corresponding emphasis on a 'capacity deficit' functions as a political tradition in its own right (see Corbett 2015a). The emphasis on capacity features in the arguments for why Westminster persists in small states, as canvassed above, but here the argument is reversed; rather than aiding democratisation, size related capacity constraints are said to undermine it.

The interaction between size and Westminster is particularly apparent in the Eastern Caribbean where countries have unicameral parliaments with fewer than 25 MPs. In St. Kitts and Nevis, for example, which has only 11 elected MPs, all government MPs are ministers. As a result, there is no group of critical backbench-parliamentarians who sincerely scrutinize 
the actions of government. In such circumstances, smallness is said to weaken the autonomy of parliament and its authority in relation to the executive. Since cabinet decisions are collective, and the speaker of parliament is often also perceived to be acting in the Prime Minister's interests, parliament functions as little more than a rubber stamp. Citing this tendency and the pervasiveness of 'vote-buying', Duncan and Woods (2007: 210-213) describe politics in the Caribbean as strongly personalized and characterized by pervasive particularistic links between citizens and politicians.

The smallness of the Eastern Caribbean island states is also said to weaken the functioning of the Westminster system in one other respect. Due to the close personal links and social intimacy that follow from small population size, people are generally aware of each other's political affiliations, resulting in the almost complete absence of political anonymity for individual citizens. In the context of strong partisan polarization, this means that the supposedly impartial and neutral functioning of Westminster institutions like the civil service, the electoral commission, the ombudsman, and the judiciary is virtually impossible to realize. As one commentator in St. Kitts and Nevis emphasized (author's interview, January 2011):

At times our democracy then becomes a fight between a government view and an opposition view, and no views in between. I think if you had more views or more people and groups with different views, then you wouldn't be so polarized and you give people almost a sense to find where the truth lies.

Rhodes et al. (2009) point to the role of a non-partisan public service as an important handbrake on executive domination in Westminster systems. The classic example is, of course, the obfuscating Sir Humphrey Appleby of Yes Minister fame. The point, they argue, is 
not that such characters exist but rather that there is enough truth in the representation as to provide civil servants with a myth that can be drawn upon to defend the erosion of their impartiality (and power). In small states, the whole question of impartiality is problematic as, to quote a common phrase: 'everybody knows everybody' (Corbett 2015c). Like the Sir Humphrey analogy, it doesn't matter whether, in a country of a few hundred thousand people, this is actually the case. But, that there is enough truth in the statement that its repetition reveals something important about the way government is practiced in these contexts, and why it is so often seen as a perversion of Weberian ideals. In small states maintaining the image of neutrality is often the greatest challenge, and supposedly neutral institutions are continuously accused of biases and preferential treatment of one party at the expense of the other(s).

There are a number of ways this debate has been reinterpreted, both in the Pacific and the Caribbean. Certainly, as Larmour (2012) points out, a relativist view highlights how the meanings of practices ordinarily labelled corrupt or deviant in one context do not always translate to another. Rather than abuse, clientelism and patronage can be reinterpreted as mechanisms for the redistribution of social welfare, which can help us to understand why they are accepted, and even demanded, by citizens (Duncan and Woods, 2007). In the Pacific, this type of conduct by elites is also often understood through a 'culturalist' lens, which focuses on the persistence of traditional leadership norms and styles in Westminster institutions. In this account, elections and parliament function as a new arena in which older norms and values about how conflict should be resolved are played out. Leaders, in this view, are expected to behave like traditional 'big-men' or 'chiefs', particularly through the provision of largesse to loyal followers (see McLeod 2007). Echoing the authenticity discussion, rather than a perversion of Weberian ideals, from this perspective Westminster is ineffective because 
it is responsible for the bastardisation of these customary 'traditions' in service of parliamentary politics.

What a comparative perspective brings to this discussion is an appreciation of how common such practices are across Westminster systems in small states, and indeed in democracies in developing countries throughout the world. In turn, this also raises important questions about explanations based on the continuation or reassertion of pre-colonial cultural practices in modern politics. However, the more central lesson is that, regardless of whether holding to a strictly legal-rational or relativist view of how government should function, Westminster is rarely seen as an effective system in the small states of the Pacific or Caribbean, with both local and international actors commonly casting these democracies as pale imitations of the practices exhibited in the five 'great self-governing dominions'. But, rather than abandon it altogether, small states have typically either adapted it to better suit their needs, either via formal innovations or informal practices.

\section{Conclusion: Comparing Westminster in Small States}

We began this discussion by highlighting four reasons commonly given to explain why small states with British colonial heritage tend to be disproportionately democratic: 1) prolonged socialization; 2) vulnerability and openness; 3) the absence of a colonial struggle; and 4) institutional fidelity. But, as our comparative examination of democratic practice in both regions highlights, all four are problematic. Prolonged socialisation maybe a feature of the Eastern Caribbean but it does little to help us understand the record of sustained democratization in the Pacific where colonial rule was comparatively light in both penetration and length. Moreover, while large-scale violent resistance to colonisation may not have been common in small states, the subsequent history of adaptation points to a more subtle and long 
lasting discussion among political actors about the appropriateness of Westminster systems in these contexts, of which anti-colonial sentiment plays a key role. Typically the delegitimization of Westminster has resulted in institutional reform, especially in the Pacific, but in extreme cases like Fiji it has led to regime change in the form of successive military coups.

Combined, our synoptic comparison reveals an underlying equivocality in the way Westminster operates in small states. There are marked similarities, including those obviously pertaining to British colonial heritage (some are "more Westminster than Westminster"), while others, like personalisation and patron client politics, appear to reflect geographic and economic factors. But, there are also considerable differences which, we have argued, stem from attempts to adapt institutions and processes designed for large states to a small state context. As Dahl and Tufte (1973: 15) highlight, smallness can have divergent and seemingly contradictory effects. That is, the highly personalized nature of political competition appears to both support aspects of democratic practice, and by extension the persistence of Westminster institutions, while others, including the concentration of power in the hands certain leaders, undermine it. Only further work can bear this equivocality out by identifying the precise conditions and circumstances under which small size leads to either outcome. For now, our aims have been more modest and fundamental: to highlight the value of bringing these two regions of the world together in the service of a comparative methodology aimed at answering long standing questions about the causes and stimuli of democratization. In doing so we have highlighted several areas in which this type of comparison challenge accepted wisdom in the field, including:

1. The limits of "culture" as a deterministic category, especially in the Pacific. In all of the states we surveyed patron-client politics was ubiquitous, ideology played a very limited role, and personalities were the basis for political contestation, voting 
behaviour, and citizen's political attachment and identification. In which case, the commonalities across both regions would appear to undermine claims that practices like "vote-buying" represent the continuation of pre-colonial cultural practice;

2. The institutionalisation of political parties. Democracy without parties is said to be impossible and yet our ostensibly similar cases reveal democracies with no parties (see Veenendaal 2016), weakly institutionalised parties, and entrenched party systems. In which case institutional design would appear to have little bearing on the emergence and development of party systems in these contexts;

3. Innovation and reform. Small states are typically said have a natural propensity to conservative policies (see most recently Sutton 2007). The fact that reform attempts in the Caribbean have often come to nothing is typically cited as evidence of this claim (but see: Bishop, 2010). By contrast, our comparison reveals that innovation and adaptation is much more common in the Pacific, a region often said to be more "traditional" thus questioning this long-standing assumption;

4. Views and perspectives of elites: Much contemporary political science analysis but especially comparative studies tend to focus on structural variables at the expense of voluntarist or agent-centred explanations. Our synoptic comparison highlights that in small states the agency of elites is a critically important and as such any account of why democracy persists or fails in these settings must, all most by definition, take their views and reflections seriously; and

5. Demonstration effects and institutional transfer. Echoing this, Kumarasingham argues that the transfer of Westminster convention relies crucially on acts of interpretation: what was unwritten in one place could not be easily written in another without deviation in practice and meaning (2013b: 583). We have engaged at length with Peter Larmour's (2005) work on institutional transfer in the Pacific. Doing so has 
highlighted how these insights might be applied to the Caribbean, including the emphasis on decisions by the post-colonial elite to persist with Westminster institutions.

This is not an exhaustive list but it does illustrate the potential of this type of work. As Ben Reilly argues, small island nations can be regarded as "natural laboratories for constitutional and electoral experimentations, but have tended to be ignored by comparative political science research" (2002, p. 355). Aside from highlighting the accuracy of this statement, our synoptic comparison illustrates the theoretical potential of this type of work for students and scholars of democratization. Therefore, we end by reiterating the call outlined at the beginning of this article for more comparative work based of the two regions. The comparative study of small states is an important subject in its own right but also has significant implications for larger political science questions, too.

\section{Acknowledgements}

The authors would like to thank Patrick Weller, Jason Sharman, and the journal's reviewers and editorial team for comments and helpful suggestions on earlier versions of this article. Any errors are, of course, our own.

\section{References}

Alesina, A, and E Spolaore (2005). The Size of Nations. Cambridge, MA: The MIT Press. Anckar, D. (2002). "Why Are Small Island States Democracies?" The Round Table 365:375390.

_ (2010). "Small Is Democratic, But Who Is Small?" Arts and Social Sciences Journal 2010: ASSJ 2:1-10.

Archer, E. (1985). "Gairyism, Revolution, and Reorganisation: Three Decades of Political Turbulence in Grenada." Commonwealth and Comparative Politics 23 (2): 91-111. 
Baldacchino, G. (1993). "Bursting the Bubble: The Pseudo-Development Strategies of Microstates." Development and Change 24 (1): 29-52.

_. 2008. "Studying islands: on whose terms? Some epistemological and methodological challenges to the pursuit of island studies." Island Studies Journal 3 (1): 37-56.

__ 2012 "Islands and despots." Commonwealth \& Comparative Politics 50 (1): 103-120.

Baldwin, N, ed. (2012). Legislatures of Small States: A Comparative Study. London: Routledge.

Barro, R. (1999). Determinants of Democracy. Journal of Political Economy 107 (6): 158183.

Bevir, M, and R.A.W. Rhodes. (2003). Interpreting British governance. Abingdon, GB: Routledge

Blyth, M. (2006). "Great punctuations: prediction, randomness, and the evolution of comparative political science." American Political Science Review 100(4): 493-498.

Bishop, M L. (2010). 'Slaying the 'Westmonster' in the Caribbean? Constitutional Reform in St Vincent and the Grenadines." The British Journal of Politics and International Relations 13 (3): 420-437.

Bourdon, R. (1993). “Towards a Synthetic Theory of Rationality”, International Studies in the Philosophy of Science 7(1): 5-19.

Burnell, P, and A Gerrits. (2010). "Promoting Party Politics in Emerging Democracies." Democratization 17 (6):1065-1084.

Burnell, P. and O Schlumberger (2010). "Promoting democracy - promoting autocracy? International politics and national political regimes", Contemporary Politics 16(1): 115

Caldwell, J., G. Harrison, and P. Quiggin. (1980). The Demography of Micro-States. World Development 8(12): 953-962.

Clague, C., S. Gleason, and S. Knack. (2001). Determinants of Lasting Democracy in Poor Countries: Culture, Development, and Institutions. Annals of the American Academy of Political and Social Science 573 (1): 16-41.

Clegg, P, and G Williams. (2013). "Editorial: The invasion of Grenada 30 years on - A retrospective". The Round Table: The Commonwealth Journal of International Affairs 102 (2): 121-126.

Corbett, J. (2015a). "Democracy in the Pacific Islands: Comparable Practices, Contested Meanings." Democratic Theory 2(2): 22-40. 
. (2015b). Being Political: Leadership and Democracy in the Pacific Islands. Honolulu: University of Hawaii Press.

. (2015c). "“Everybody knows Everybody": Practising Politics in the Pacific Islands." Democratization 22(1): 51-72.

Corbett, J, and T. Wood. (2013) "Profiling politicians in Solomon Islands: Professionalization of a political elite?" Australian Journal of Political Science 48(3): 320-334

Crowards, T. (2002). "Defining the category of "small" states." Journal of International Development 14 (2):143-179.

Diamond, L J., and S Tsalik. (1999). "Size and Democracy: the Case for Decentralization." In Developing Democracy: Towards Consolidation, ed. L. J. Diamond. Baltimore, MD: The John Hopkins University Press

Duncan, N T., and D Woods. (2007). "What About Us? The Anglo-Caribbean Democratic Experience." Commonwealth and Comparative Politics 45 (2):202-218.

Duncan, R, and G Hassall. (2011). "How Pervasive is Clientelist Politics in the Pacific?” In R. Duncan (Ed.), The Political Economy of Economic Reform in the Pacific. Mandaluyong City, Philippines: Asian Development Bank.

Erk, J., and W. Veenendaal. (2014) "Is Small Really Beautiful?: The Microstate Mistake." Journal of Democracy 25(3): 135-148.

Fraenkel, J. (2004). "Electoral Engineering in Papua New Guinea: Lessons from Fiji and Elsewhere." Pacific Economic Bulletin 19 (1):122-133.

- (2012). "Party-hopping laws in the southern hemisphere." Political Science 64(2): 106-120

Gerring, J. (2012). "Mere description." British Journal of Political Science 42(4): 721-746.

Girvan, N. (2015). Assessing Westminster in the Caribbean: Then and Now. Commonwealth and Comparative Politics 53 (1): 95-107.

Ghai, Y. (1988). Law, Politics, and Government in the Pacific Island States. Suva: University of the South Pacific Press.

Hadenius, A. (1992). Democracy and Development. Cambridge: Cambridge University Press.

Hall, P.A., and R.C. Taylor (1996). "Political Science and the Three New Institutionalisms." Political Studies, 44: 936-957.

Hau'ofa, E. (1994). “Our Sea of Islands.” The Contemporary Pacific 6 (1): 147-161.

Hinds, D. (2008). "Beyond Formal Democracy: The Discourse on Democracy and Governance in the Anglophone Caribbean." Commonwealth and Comparative Politics 46 (3):388-406. 
Hoefte, R., and G. Oostindie. (1991). The Netherlands and the Dutch Caribbean: Dilemmas of Decolonization. In Paul Sutton (ed.). Europe and the Caribbean. London: MacMillan.

Iati, I. (2013). "Samoa's Price for 25 Years of Political Stability." The Journal of Pacific History 48(4): 443-463.

Jolly, M. (2002). "Spectres of Inauthenticity." In David Hanlon and Geoffrey White, eds. Voyaging through the contemporary Pacific. Cumnor Hill and Oxford: Rowman and Littlefield Publishers Inc., pp 274-298.

Kumarasingham, H. 2013a. A Political Legacy of the British Empire: Power and the Parliamentary System in Post-Colonial India and Sri Lanka. IB Tauris.

— 2013b "Exporting executive accountability? Westminster legacies of executive power." Parliamentary Affairs 66(3): 579-596.

Kinyondo, A, and R Pelizzo. (2013). "Strengthening Legislatures: Some Lessons from the Pacific Region.” Politics and Policy 41 (3):420-446.

Laban, M. (2014). "More Westminster than Westminster? The Office of Speaker across the Commonwealth.” The Journal of Legislative Studies 20 (2):143-155.

Larmour, P. (2005a). Foreign Flowers: Institutional Transfer and Good Governance in the Pacific Islands. Honolulu: University of Hawaii Press.

. (2005b). "Westminster in the Pacific Islands". In Westminster Legacies: democracy

and responsible government in Asia and the Pacific. H. Patapan, J. Wanna and P.

Weller, eds. Sydney, University of New South Wales Press.

. (2012) Interpreting Corruption: Culture and Politics in the Pacific Islands.

Honolulu: University of Hawai'i Press.

Lawson, S. (1996). Tradition Versus Democracy in the South Pacific: Fiji, Tonga and Western Samoa. Cambridge: Cambridge University Press.

- (2006). Culture and Context in World Politics, London: Palgrave Macmillan.

Levine, S. (1992). "Constitutional change in Tuvalu." Politics 27(3): 492-509.

Lijphart, A. (1999). Patterns of Democracy. New Haven: Yale University Press.

McLeod, A. (2007). "Leadership Models in the South Pacific." State, Society, and Governance in Melanesia Discussion Paper, No. 6. Canberra: The Australian National University. 
Ott, D. (2000). Small is Democratic: An Examination of State Size and Democratic Development. New York: Garland.

Panapa, P. and Fraenkel, J. (2008). The Loneliness of the Pro-Government Backbencher and the Precariousness of Simple Majority Rule in Tuvalu. SSGM Discussion Paper 2008/2. Canberra: State, Society and Governance in Melanesia Program, The Australian National University.

Patapan, H., J. Wanna, and P. Weller, eds. (2005). Westminster Legacies: Democracy and Responsible Government in Asia and the Pacific. Sydney: University of New South Wales Press.

Paeniu, L. (2012). "How Can Parliamentary Democracy Function More Effectively in Small Pacific Island Countries Such as Tuvalu and Nauru?" Journal of South Pacific Law 14(2): 6-19.

Payne, A. (1993). "Westminster Adapted: the political order of the Commonwealth Caribbean". In Democracy in the Caribbean, Domínguez, Jorge I., Robert A. Pastor, and R. DeLisle Worrell, eds. Baltimore: Johns Hopkins University Press, pp 57-73.

Payne, D. (1993). “Caribbean Democracy”. Freedom Review 10(3): 1-19.

Peters, D C. (1992). The Democratic System in the Eastern Caribbean. New York: Greenwood Press.

Przeworski, A., M Alvarez, J A Cheibub, and F Limongi. (2000). Democracy and development: political institutions and well-being in the world, 1950-1990. Cambridge: Cambridge University Press.

Quinn, K, ed. (2013). Black Power in the Caribbean. University Press of Florida. . (2015). Introduction: Revisiting Westminster in the Caribbean. Commonwealth and Comparative Politics 53 (1): 1-7.

Ravuvu, A. (1991). The facade of democracy: Fijian struggles for political control, 18301987. Suva, Fiji: Reader Publishing House

Reilly, B. (2001). "Evaluating the Effect of the Electoral System in Post-Coup Fiji." Pacific Economic Bulletin 16 (1):142-149.

Reilly, B. (2002). "Social Choice in the South Seas: Electoral Innovation and Borda Count in the Pacific Island Countries.” International Political Science Review, 23 (4): 355-372.

Rhodes, R.A.W., J Wanna, and P Weller. (2009). Comparing Westminster. Oxford: Oxford University Press.

Rhodes, R.A.W. (2014). “'Genre Blurring' and Public Administration: What Can We Learn from Ethnography?” Australian Journal of Public Administration. 73(3): 317-330. 
Ryan, S D. (1999). Winner Takes All: the Westminster Experience in the Caribbean. St. Augustine, Trinidad: University of the West Indies Press.

So'o, A. (2008). Democracy and Custom in Samoa. Suva, Fiji: IPS Publications.

Srebrnik, H. (2004). "Small Island Nations and Democratic Values." World Development 32 (2):329-341.

Sutton, P. (1999). "Democracy in the Commonwealth Caribbean." Democratization 6(1):6786.

(1987). "Political Aspects". In Politics, Security, and Development in Small States, ed. C. Clarke and A. Payne. London: Allen \& Unwin.

(2007). Democracy and Good Governance in Small States. In E. Kisanga and S. Danchie (eds.), Commonwealth Small States: Issues and Prospects. London: Commonwealth Secretariat.

Sutton, P, and A Payne. (1993). "Lilliput Under Threat: The Security Problems of Small Island and Enclave Developing States". Political Studies 41(4): 579-593.

Thorndyke, T. (1993). "Revolution, Democracy, and Regional Integration in the Eastern Caribbean." In Payne, Anthony, and Paul Sutton (eds.), Modern Caribbean Politics. Baltimore, MD: The Johns Hopkins University Press.

Underwood, R. (2006). "Micronesian political structures and US models: lessons taught and lessons learned." The Journal of Pacific Studies 29(1): 4-24.

Veenendaal, W.P. (2013). "Political Representation in Microstates: St. Kitts and Nevis, Seychelles, and Palau." Comparative Politics, 45 (4): 437-456.

- (2014). Politics and Democracy in Microstates. London: Routledge.

. (2016) "How Democracy Functions without Parties The Republic of Palau." Party Politics, 22 (1): 27-36.

Veenendaal, W.P., and J. Corbett. (2015). "Why Small States Offer Important Answers to Large Questions.” Comparative Political Studies, 48 (4): 527-549.

Weiner, M. (1987). "Empirical Democratic Theory and the Transition from Authoritarianism to Democracy." PS: Political Science \& Politics 20 (4): 861-866.

Wettenhall, R, and I Thynne. (1994). "Machinery of Government Innovation in Micro-States: The Cases of Nauru, Niue, and Norfolk Island." Asian Journal of Public Administration 16 (1): 60-86. 